\title{
Woody Plant Species Diversity of Dembeza Natural Forest, Enebsae Sarmider District, North Western Ethiopia
}

\author{
Tensay Ayalew ${ }^{1}$, Sisay Alemu ${ }^{2}$ \\ ${ }^{1}$ Forest and Range Land Biodiversity Case Team, Bahir Dar Biodiversity Centre, Bahir Dar, Ethiopia \\ ${ }^{2}$ Forest and Range Land Biodiversity Case Team, Ethiopian Biodiversity Institute, Addis Ababa, Ethiopia
}

Email address:

tensaye2006@gmail.com (T. Ayalew)

\section{To cite this article:}

Tensay Ayalew, Sisay Alemu. Woody Plant Species Diversity of Dembeza Natural Forest, Enebsae Sarmider District, North Western Ethiopia. Journal of Plant Sciences. Vol. 9, No. 4, 2021, pp. 175-181. doi: 10.11648/j.jps.20210904.17

Received: July 21, 2021; Accepted: August 5, 2021; Published: August 26, 2021

\begin{abstract}
The natural forest in Ethiopia has significant contribution to the ecological and economy of the country. The study was conducted at Dembeza natural forest to explore woody plant species diversity. Systematic and predetermined sampling method was followed to collect the inventory data. The main objective of the study was to undergo inventory of indigenous woody plant species, record regeneration status, determining floristic composition and list out the plant species which have threatened and need immediate conservation. The study was conducted during December to January 2021. A total of four transect and 40 plots were used to collect the inventory data. From the natural forest a total of 66 plant species belongs to 41 families were recorded. The life form distribution of this species was 2 (3.17\%) herb, 4 (6.34\%) liana, $41(65.07 \%)$ shrub and $16(25.39 \%)$ tree. Fabaceae was found the most species rich families comprising $7(11.11 \%)$ also Lamiaceae and Celastraceae follow with the same $4(6.34 \%)$. The variation of the species frequency ranges between $2.5-85 \%$ showing high heterogeneity in species distribution. Among those Acacia lahai 2.5\%, Ekebergia capensis 2.5\% Apodytes dimidiata 5\% held less in distribution while, Abutilon figarianum $22.5 \%$, Acacia abyssinica $60 \%$, Carissa spinarum $65 \%$ and Croton macrostachyus $85 \%$ are comparatively recorded high in frequently appearing or widely distributed woody plant species. The total seedling density per hectare of the forest was 6606.25, which have highest density in the forest were Juniperus procera (206.25), Acanthus sennii (218.75), Carissa spinarum (381.25), Myrsine africana (293.75), Calpurnia aurea (418.75) and top Croton macrostachyus (1375). While species which have lowest density were Acacia lahai, Acokanthera schimperi, Calusena anisata, Dovyalis abyssinica, Dodonaea angustifolia, Rhus glutinosa, Rosa abyssinica, Steganotaenia araliacea which mean species not recorded seedling during the inventory. The major factor recorded in the forest were browsing, cutting and logging. Minimizing human intervention, eradicating of invasive alien species and prevent forest disturbance should applied in Dembeza natural forest.
\end{abstract}

Keywords: Conservation, Forest, Dembeza, Disturbance, Inventory

\section{Introduction}

Ethiopia is one of the few countries in the world that posses unique characters of flora and fauna with high endemic species [1]. The flora of Ethiopia estimated from 6500 to 7000 plant species with high endemic in number [1]. The country has great geographical diversity with different agro ecological zones [7]. That play great role for great diversity of animal, plant and microbial genetic resources [2]. The natural forest in Ethiopia has significant contribution to the ecological and economy of the country, most of the natural vegetation is highly degraded [3]. The natural vegetation affected by different factors among those agricultural exploitation, illegal settlement, deforestation and invasive alien species, human dependence for fuel wood, non timber forest products, and grazing of livestock are the main $[15,4,5]$. The forests in northern highlands are found only as isolated small patches at inaccessible locations and around the numerous churches and burial grounds [6]. Conservation and sustainable utilization of natural resource use to eradicate poverty [8]. In Ethiopia there is change on plantation of trees or maintain the existing trees as an agroforestry practice Which in agroecological, socio-economic, cultural, institutional and personal factors [9]. Plantation practice is better on woody species diversity on their land holdings [10]. Dembeza natural forest is one of the greatest gene pools for the indigenous plant species that has not been 
investigated. This study was conducted with the objective of inventory data collection on the woody species composition and structure, investigating the woody species diversity and richness with the regeneration status of the forest.

\section{Materials and Methods}

\subsection{Description of the Study Area}

Dembeza forest is located in EnbiseSarMidir district of east Gojjam zone Amhara regional state at about $220 \mathrm{~km}$ from Bahir Dar capital city of Amhara region. This district is named in part after the historic district of Enbise, which was first mentioned in the 16th century. Part of the east Gojjam zone Enbise Sar Midir is bordered on the south by Enarj Enawga, on the west by Goncha Siso Enese, and on the north and east by Abay River which separates it from the Debub Gondar Zone and Debub Wollo Zone. The administrative center of this district is Mertule Mariam. Based on [16] this district has a total population of 133,855 , an increase of $23.20 \%$ over the 1994 census, of whom 66,139 are men and 67,716 women; 12,259 or $9.16 \%$ are urban inhabitants.

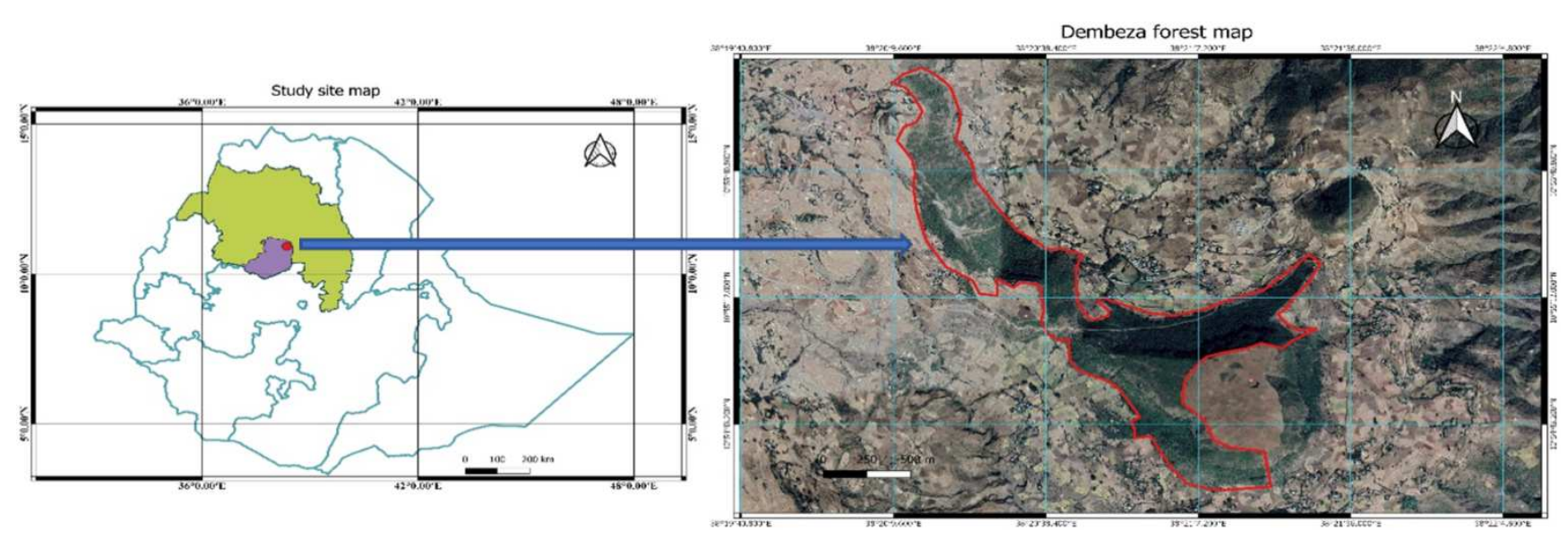

Figure 1. Study area map.

\subsection{Materials}

There are materials used during the inventory and study. Thus, are compass, measuring tap, digital camera, not book, data sheet, GPS (digital positioning system), DSH/DBH measurement (caliper) meter, laptop computer, pressing materials and plastics.

\subsection{Methods}

\subsubsection{Sampling System and Design}

The forest inventory was conducted in 2013/2021 for 20 consecutive days in Dembeza natural forest systematic and predetermined sampling techniques were followed. Data were collected in the main quadrate of $50 \mathrm{mx} 10 \mathrm{mx}$ size and a sub-quadrate of $10 \mathrm{mx}^{2}$ size was established within the main quadrate at the longest side of both ends. A total of 40 plots within $20000 \mathrm{~m}^{2}$ were discovered and representative plant specimens with basic information/passport date were collected.

\subsubsection{Transect and Quadrate Layout}

Four transect were laid along the gentle to flat landscapes perpendicular to the base line. The gravel rods either crossing or bordering the vegetation were used as a base line. The forest and the second transect were laid to the north east, the 3 rd to the southeast, the 4 th and the 5 th laid to the south east direction. The transect were $200 \mathrm{~m}$ far apart each other and the quadrates were established with regular interval of $200 \mathrm{~m}$ from each other. In general a total of 4 transects, 40 quadrates were used to collect the inventory data from the Dembeza natural forest.

\subsection{Data Collection}

Topographic characteristics slop gradient and depth, slop position and aspect were collected following the woody plant species diversity assessment field manual organized by Ethiopian Institute of Biodiversity. To collect the vegetation data woody plant species inventory and regeneration status assessment form were used. Each woody plant species appeared in the sample plots and for trees and shrubs having the DBH2.5 cm, DSH/DBH was measured using the graduated caliper. For shrubs possessing several steams were also counted duly. The data of sapling and seedling of woody plant species were recorded from Dembeza natural forest.

\section{Results and Discussions}

Environmental Data: Land use/land cover of the study area showed as open woodland, wooded shrub land and bush land. Her were factors which are observed and recorded during the study in and around the forest. Thus are grazing, deforestation agricultural explanation cutting, flooding, invasive plant species, less concern of community to the forest, illegal house constriction around forest bounders.

\subsection{Forest Disturbance}

Dembeza natural forest subjected factors like 
deforestation for settlement and agricultural explanation; over utilization particularly selected plant species by the community. The above listed and other factors are cause for the loss of species diversity and distribution. During the study result for the forest disturbance showed that browsing, cutting and logging (Table 1). Similar study conducted by [11], because of unlimited human disturbance the natural forest of the Ethiopia was fragmented into small isolated forest patches now largely restricted in the gorges and other inaccessible areas. In contrast study conducted by [12], community awareness on the importance of forest resources and its link with biodiversity, ecosystem services and human wellbeing in Ethiopia is increasing and forests are planted and conserved.

Table 1. Forest disturbance type and scale.

\begin{tabular}{|c|c|c|c|c|c|c|c|}
\hline \multirow{2}{*}{ Forest Name } & \multirow{2}{*}{ Disturbance type } & \multicolumn{5}{|c|}{ Disturbance scale } & \multirow{2}{*}{ Total } \\
\hline & & 1 (Negligible) & 2 (Light) & 3 (Moderate) & 4 (Intensive) & 5 (Heavy) & \\
\hline \multirow{3}{*}{ Dembeza forest } & Browsing & 12 & 14 & 6 & - & - & 32 \\
\hline & Grazing & 12 & 35 & 4 & - & - & 50 \\
\hline & Logging & & 14 & 4 & - & - & 18 \\
\hline
\end{tabular}

Where; 1 (Negligible) 0-20\%, 2 (Light) 20-40\%, 3 (Moderate) 40-55\%, 4 (Intensive) 55-70\%, 5 (/Heavy) above 70\% Total (\%).

Geographical Aspects: The geographical aspect with slop position of the study area is upper, middle, lower and altitude, slop gradient, aspect soil depth and bearing are registered. As indicated in Table 2, the data were taken from eight topographic aspects and at three slope positions $(2460-2720$ m.a.s.1.) and within the $11-48 \%$ slope gradients.

Table 2. Topographic features and level of forest disturbance.

\begin{tabular}{|c|c|c|c|c|c|c|c|}
\hline $\begin{array}{l}\text { Slope } \\
\text { position }\end{array}$ & $\begin{array}{l}\text { Altitude } \\
\text { (m.a.s.l.) }\end{array}$ & $\begin{array}{l}\text { Slope } \\
\text { gradient }(\%)\end{array}$ & Aspect & $\begin{array}{l}\text { Number of } \\
\text { quadrates }\end{array}$ & $\begin{array}{l}\text { Forest disturbance } \\
\text { types }\end{array}$ & $\begin{array}{l}\text { Forest disturbance } \\
\text { intensity }\end{array}$ & $\begin{array}{l}\text { Proportion of } \\
\text { sample plots (\%) }\end{array}$ \\
\hline Upper & $2460-2545$ & $11-27$ & NW, S, E & 7 & $\begin{array}{l}\text { Browsing, Grazing } \\
\text { and logging }\end{array}$ & Negligible & 17.5 \\
\hline Middle & $2546--2631$ & $25-42$ & All except S \& SW & 19 & & Light & 47.5 \\
\hline Lower & $2632-2720$ & $40-48$ & All Aspect & 14 & & Moderate & 35 \\
\hline Total & & & & 40 & & & 100 \\
\hline
\end{tabular}

\subsection{Floristic Composition}

From the study area of Dembeza natural forest a total of 66 plant species were collected, out of which 63 were identified and the rest 3 were recorded by their local name. The plant species lays on 41 families with the dominant number of Fabaceae. In floristic analysis 66 woody plant species belonging to 41 families were identified in protected natural vegetation. Which lie in altitudinal range between 2460 and 2716 m.a.s.l. the life form distribution of this species were 2 $(3.17 \%)$ herb, $4(6.34 \%)$ liana, $41(65.07 \%)$ shrub and 16 $(25.39 \%)$ tree. Fabaceae was found the most species rich families comprising $7(11.11 \%)$ also Lamiaceae and Celastraceae with the same 4 (6.34\%).

\subsection{Species Dimensions}

The maximum height recorded in Dembeza natural forest was $32 \mathrm{~m}$ by Albizia gummifera plant species. While, the maximum DBH/DSH was $46 \mathrm{~cm}$ by species Schefflera abyssinica species. The tree species highest in terms of mean height $(10.93 \mathrm{~m})$ and mean DBH/DSH $(46.20 \mathrm{~m})$. The maximum number of steams sampled and measured was for other tree species that are the most frequently appearing in the inventoried Dembeza natural forest. On the other hand the least size of DSH/DBH and total height recorded was $2.5 \mathrm{~cm}$ and $3 \mathrm{~m}$ respectively.

\subsection{Frequency and Relative Frequency of Woody Species}

The result of the study showed that the variation of the species frequency ranges between 2.5-85\%. This showed that there is high heterogeneity in species distribution in Dembeza natural forest. Among those Acacia lahai 2.5\%, Ekebergia capensis 2.5 Apodytes dimidiata 5\% held less in distribution while, Abutilon figarianum 22.5\%, Acacia abyssinica $60 \%$, Carissa spinarum $65 \%$ and Croton macrostachyus $85 \%$ are comparatively recorded high in frequently appearing or widely distributed woody plant species.

\subsection{Density and Relative Density of Woody Species}

The density of a given species is expressed as a number of stems per hectare. Species were classified in to five density classes, A-E as follows: $\mathrm{A}>100.1 ; \mathrm{B}=50.1-100 ; \mathrm{C}=10.1-50$; $\mathrm{D}=1.1-10$ and $\mathrm{E}=<1$. Six species were fall in density class $A$, four species in density class B, sixteen species in density class $\mathrm{C}$, twenty species in density class D and four species were found in density class E. In Denbeza natural forest the highest density of species was recorded species like Apodytes dimidiata, Vernonia amygdalina, Dombeya torrid, Euclea racemosa and Ficus sur. 
Table 3. Species density class and distribution.

\begin{tabular}{lllll}
\hline Species density class & Total density & Relative density & Number of species & Proportion (\%) \\
\hline A $(>100)$ & 1147 & 59.51 & 6 & 11.76 \\
B $(50.1-100)$ & 307 & 15.93 & 4 & 7.84 \\
C $(20.1-50)$ & 292.5 & 15.18 & 10 & 19.61 \\
D $(1-20)$ & 180 & 9.34 & 29 & 56.86 \\
E $(<1)$ & 1 & 0.06 & 2 & 3.92 \\
Total & 1927.5 & 100 & 51 & 100 \\
\hline
\end{tabular}

\subsection{Stand Diameter and Height Profile}

\subsubsection{Stand Height Value}

In determining the stand height profile $\mathrm{A}(5 \mathrm{~m}), \mathrm{B}(5.1-10 \mathrm{~m})$, C (10.1-15m), E $(20.1-20 \mathrm{~m})$ and $F(>25 \mathrm{~m})$ the result from analysis showed that $>5 \mathrm{~m} 43$ species exist, 5.1-10m 23 species, 10.1-15m 4 species, 15.1-20m 3 species and $>20 \mathrm{~m} 2$ species. This indicates that the majority of species belongs to in group A and list numbers of species exist in class F. in Dembeza natural forest Croton macrostachyus and Albizia gummifera were exist in species class F. This showed that cutting is highly practiced inside the forest.

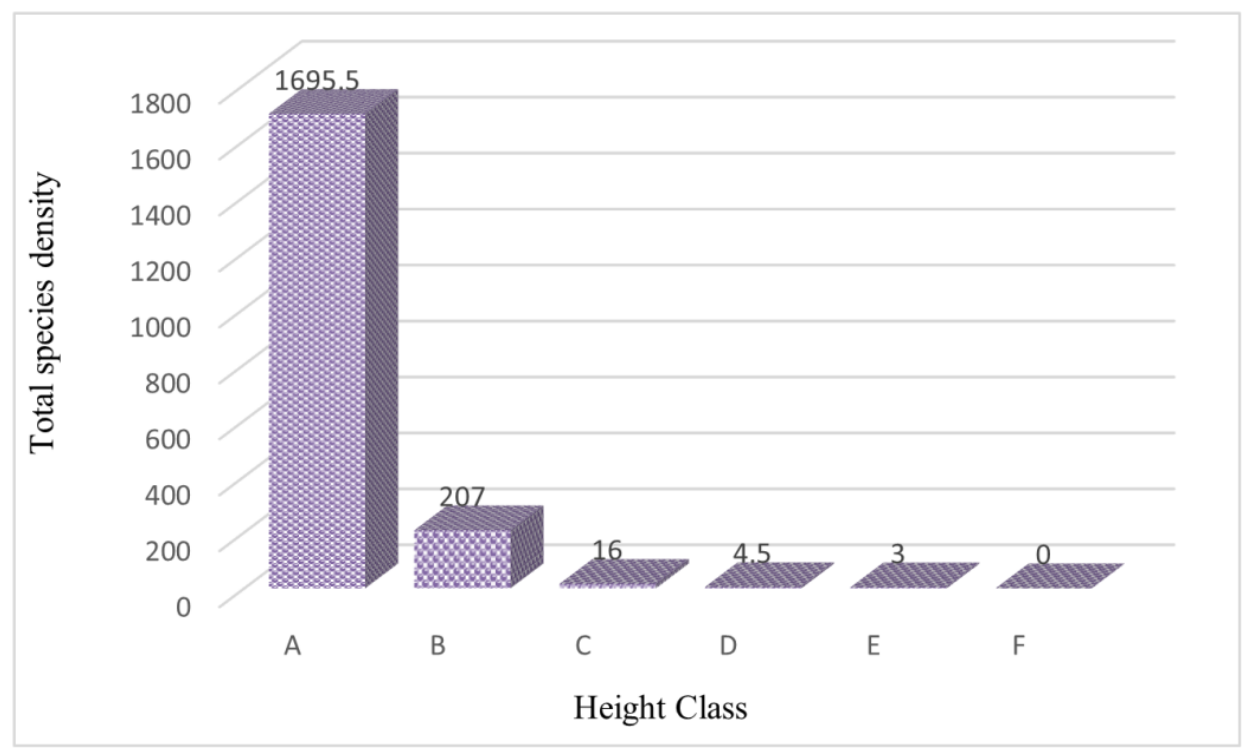

Figure 2. Number and total species density by height class.

\subsubsection{Stand Diameter Profile}

The diameter classes in the forest were putted in nine groups. A 2.6-7.5 cm); B (7.6-12.5 cm); C (12.6-17.5 cm); D $(17.6-22.5$ $\mathrm{cm})$; E 22.6-27.5 cm); F (27.6-32.5 cm); G 32.6-37.5 cm); H $(37.5-42.5 \mathrm{~cm})$ and $\mathrm{I}(>42.6 \mathrm{~cm})$. The result showed that majority of species were recorded in group A $(2.6-7.5 \mathrm{~cm})$. The lowest numbers of tree species were recorded in group E, F, G, $\mathrm{H}$ and I classes. This indicates those mature trees which attend in the higher diameter size should have been selectively exploited by the local community live near by the forest.

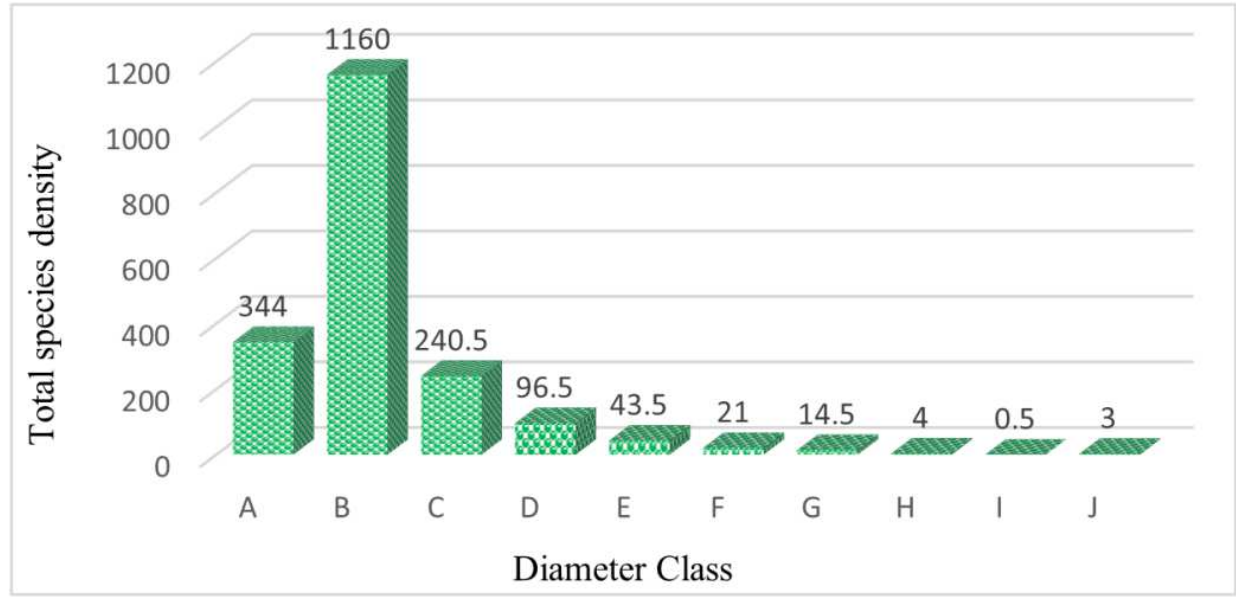

Figure 3. Number and total species density by diameter class. 


\subsection{Basal Area and Dominance of Woody Plant Species}

The total basal area for the inventoried woodland is 18.39 the biggest basal area recorded by plant Ficus sur which is $0.050 \mathrm{~m}^{2}$ while the largest dominance and relative dominance were held by one species called Croton macrostachyus $(1.84 \mathrm{~m} / \mathrm{ha})$ and $(19.92 \%)$ respectively. Other species which are recorded in top range in terms of dominance were Acacia abyssinica $(1.28 \mathrm{~m} / \mathrm{ha}$ ) Juniperus procera $(0.99 \mathrm{~m} / \mathrm{ha})$, Albizia gummifera $(0.7 \mathrm{~m} / \mathrm{ha})$ and Allophylus abyssinicus $(0.61 \mathrm{~m} / \mathrm{ha})$.

\subsection{Regeneration Status}

The density of seedling and sapling for woody species were analyzed to record regeneration status of the forest. The seedling status was recorded for 41 plant species. This becomes $87.23 \%$ have recorded seedling and sapling in the natural forest. The total seedling density per hectare was 6606.25. The species which have highest density in the forest were Juniperus procera (206.25), Acanthus sennii (218.75), Carissa spinarum (381.25), Myrsine Africana (293.75), Calpurnia aurea (418.75) and top Croton macrostachyus (1375). While species which have lowest density were Acacia lahai, Acokanthera schimperi, Calusena anisata, Dovyalis abyssinica, Dodonaea angustifolia, Rhus glutinosa, Rosa abyssinica, Steganotaenia araliacea which mean species not recorded seedling during the inventory. To sum up the seedling regeneration status the analysis result showed low and show the intensive trampling by livestock, browsing and grazing in the forest with less germination from soil seed bank are the main reason for the less recorded of seedling in Dembeza natural forest. Study conducted by [13], that the major factors contributed for lack of regeneration for some woody species could be a result of existing disturbance in the study areas like, free grazing, firewood collection, and poor biotic potential of tree species; these could either affect the fruiting or seed germination or successful conversion of seedling to sapling stage.

\subsection{Vegetation Environmental Relation Ship Floristic Richness by Aspect}

The result of the study pointed out that the species distribution varies with aspects. In accord with this, about $21.6 \%$ of the species were recorded from the northwest, $13.7 \%$ from East and North respectively, $11.8 \%$ from southwest and northeast respectively, $15.7 \%$ from west and $5.9 \%$ on south and southeast direction of the forest topographic feature. In terms of the individual species, maximum number of woody plant species (11) was inventoried on the northwest direction followed by eight species in east aspects as depicted in Figure 4. This entails that the floristic composition of plant species is affected by aspects and vary accordingly.

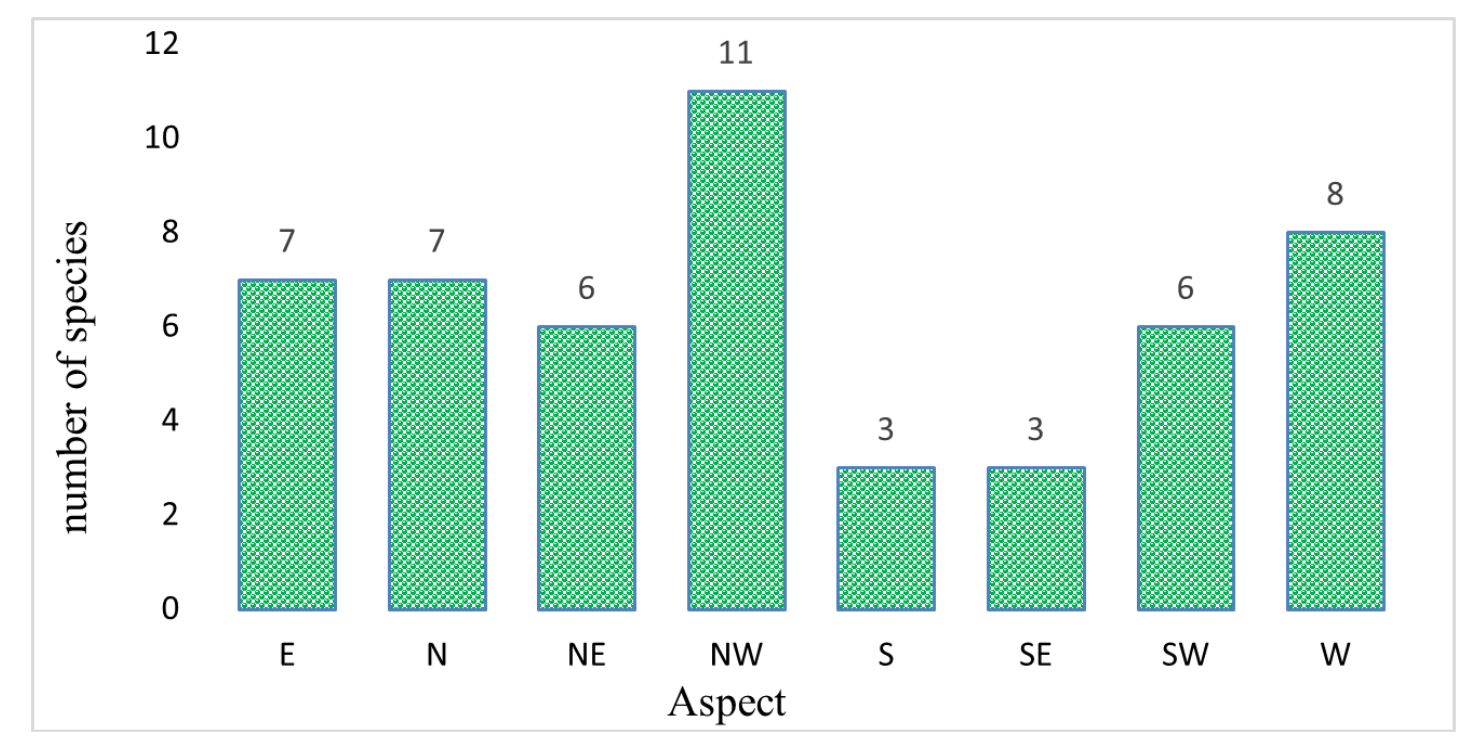

Figure 4. Number of species recorded as per the topographic aspects.

\subsection{Importance Value Index}

The ecological significance of the structure of the tree species in community structure is known in IVI values [14]. In this case, the IVI value of species of Dembeza forest calculated relative density, relative dominance and relative frequency Croton macrostachyus (34.41) Acacia abyssinica (24.48) Acanthus sennii (19.39) and Maytenus obscura (19.35) were recorded relatively higher values.
The lower IVI class indicates that those species are threatened and should take action for conservation. In Dembeaz forest species which has $<1$ IVI were Apodytes dimidiate (0.64), Cordia Africana (0.85), Ekebergia capensis (0.43), Euclea racemosa (0.6), Jasminum abyssinicum (0.92), Leonotis ocymifolia (0.28) are among species which need immediate action for conservation on ecological values of the species. 
Table 4. Relative density $(R D)$, relative dominance $(R D)$, relative frequency $(R F)$ and Importance value index $(I V I)$ of plant species.

\begin{tabular}{|c|c|c|c|c|c|c|c|c|}
\hline No & Scientific name & Local name & RD & RDO & RF & IVI & Percent & Rank \\
\hline 1. & Abutilon figarianum & Nechachile & 1.56 & 0.35 & 2.2 & 4.11 & 1.4 & 18 \\
\hline 2. & Acacia abyssinica & Girar & 4.77 & 13.86 & 5.85 & 24.48 & 8.2 & 3 \\
\hline 3. & Acacia lahai & Chebagirar & 0.08 & 0.03 & 0.24 & 0.35 & 0.1 & 49 \\
\hline 4. & Acanthus sennii & Kosheshila & 13.18 & 2.31 & 3.9 & 19.39 & 6.5 & 4 \\
\hline 5. & Acokanthera schimperi & Meranze & 1.12 & 0.42 & 1.22 & 2.76 & 0.9 & 25 \\
\hline 6. & Albizia gummifera & Sesiye & 0.99 & 7.64 & 2.68 & 11.31 & 3.8 & 10 \\
\hline 7. & Allophylus abyssinicus & Embis & 4.49 & 6.61 & 5.37 & 16.47 & 5.5 & 7 \\
\hline 8. & Apodytes dimidiata & Donga & 0.13 & 0.02 & 0.49 & 0.64 & 0.2 & 40 \\
\hline 9. & Bersama abyssinica & Azamera & 2.7 & 3.13 & 3.41 & 9.24 & 3.1 & 12 \\
\hline 10. & Buddleja polystachya & Anfar & 1.97 & 2.24 & 2.44 & 6.65 & 2.2 & 13 \\
\hline 11. & Calpurnia aurea & Digita & 3.97 & 1.42 & 3.9 & 9.29 & 3.1 & 11 \\
\hline 12. & Carissa spinarum & Agam & 7.03 & 1.7 & 6.34 & 15.07 & 5.0 & 9 \\
\hline 13. & Cassipoure amalosana & Tekurinchet 2 & 0.47 & 0.33 & 0.49 & 1.29 & 0.4 & 31 \\
\hline 14. & Clerodendrummyricoides & Miserch/Un1 & 0.96 & 0.16 & 2.2 & 3.32 & 1.1 & 21 \\
\hline 15. & Clutia abyssinica & Fyelefej & 0.96 & 0.15 & 1.71 & 2.82 & 0.9 & 23 \\
\hline 16. & Colutea abyssinica & Un1 / fabaceae & 1.22 & 0.31 & 1.46 & 2.99 & 1.0 & 22 \\
\hline 17. & Cordia africana & Wanza & 0.08 & 0.53 & 0.24 & 0.85 & 0.3 & 38 \\
\hline 18. & Croton macrostachyus & Bisana & 6.2 & 19.92 & 8.29 & 34.41 & 11.5 & 1 \\
\hline 19. & Dodonaea angustifolia & Kitkita & 14.5 & 4.46 & 7.8 & 26.76 & 8.9 & 2 \\
\hline 20. & Dombeya torrid & Wolkifa & 0.36 & 0.63 & 0.98 & 1.97 & 0.7 & 29 \\
\hline 21. & Dovyalis abyssinica & Koshim & 1.58 & 1.49 & 1.71 & 4.78 & 1.6 & 16 \\
\hline 22. & Ekebergia capensis & Lol & 0.05 & 0.14 & 0.24 & 0.43 & 0.1 & 46 \\
\hline 23. & Euclea racemosa & Dedeho & 0.1 & 0.01 & 0.49 & 0.6 & 0.2 & 43 \\
\hline 24. & Ficus sur & Shola & 0.16 & 1.59 & 0.49 & 2.24 & 0.7 & 26 \\
\hline 25. & Ficus vasta & Warka & 0.13 & 0.83 & 0.24 & 1.2 & 0.4 & 32 \\
\hline 26. & Grewia ferruginea & Lenkuata & 1.95 & 0.57 & 1.71 & 4.23 & 1.4 & 17 \\
\hline 27. & Jasminum abyssinicum & Tembelel & 0.18 & 0.01 & 0.73 & 0.92 & 0.3 & 36 \\
\hline 28. & Juniperus procera & MisarGenfo & 1.56 & 10.74 & 4.15 & 16.45 & 5.5 & 8 \\
\hline 29. & Leonotis ocymifolia & Tsid & 0.03 & 0.01 & 0.24 & 0.28 & 0.1 & 50 \\
\hline 30. & Maytenus gracilipes & Dabiza & 0.57 & 5.17 & 0.73 & 6.47 & 2.2 & 14 \\
\hline 31. & Maytenus obscura & Atat & 12.32 & 0.44 & 6.59 & 19.35 & 6.5 & 5 \\
\hline 32. & Maytenus undata & GeramAtat & 0.26 & 0.2 & 0.49 & 0.95 & 0.3 & 35 \\
\hline 33. & Myrsine africana & Qechema & 0.36 & 0.05 & 0.49 & 0.9 & 0.3 & 37 \\
\hline 34. & Nuxia congesta & Atequar/Asquare & 0.1 & 0.01 & 0.49 & 0.6 & 0.2 & 43 \\
\hline 35. & Oleae europaea & Waira & 1.35 & 1.42 & 2.2 & 4.97 & 1.7 & 15 \\
\hline 36. & Olinia rochetiana & Tefi & 6.28 & 7.88 & 5.12 & 19.28 & 6.4 & 6 \\
\hline 37. & Osyris quadripartita & Qerete & 0.88 & 0.19 & 2.68 & 3.75 & 1.3 & 19 \\
\hline 38. & Otosteg iaintegrifolia & Tunjut/Tuzit & 1.37 & 0.21 & 1.22 & 2.8 & 0.9 & 24 \\
\hline 39. & Pavetta abyssinica & Chicho & 0.29 & 0.08 & 0.73 & 1.1 & 0.4 & 34 \\
\hline 40. & Pittosporumvi ridiflorum & Un2 / Pitosporum & 0.36 & 0.18 & 0.98 & 1.52 & 0.5 & 30 \\
\hline 41. & Proteaga guedi & Awera & 0.36 & 0.43 & 1.22 & 2.01 & 0.7 & 28 \\
\hline 42. & Prunus africana & Tekurinchet & 0.1 & 0.02 & 0.49 & 0.61 & 0.2 & 42 \\
\hline 43. & Rhamnus prinoides & Gesho & 0.13 & 0.01 & 0.24 & 0.38 & 0.1 & 48 \\
\hline 44. & Rhus glutinosa & Takima & 0.16 & 0.16 & 0.49 & 0.81 & 0.3 & 39 \\
\hline 45. & Rhus retinorrhoea & Telem & 0.26 & 0.04 & 0.24 & 0.54 & 0.2 & 45 \\
\hline 46. & Rosa abyssinica & Qega & 1.5 & 0.29 & 1.95 & 3.74 & 1.2 & 20 \\
\hline 47. & Salix subserrata & Akiya & 0.05 & 0.33 & 0.24 & 0.62 & 0.2 & 41 \\
\hline 48. & Schefflera abyssinica & Getem & 0.03 & 0.91 & 0.24 & 1.18 & 0.4 & 33 \\
\hline 49. & Steganotaenia araliacea & Yejibbeter & 0.08 & 0.01 & 0.49 & 0.58 & 0.2 & 44 \\
\hline 50. & Vernonia amygdalina & Gerawa & 0.13 & 0.03 & 0.24 & 0.4 & 0.1 & 47 \\
\hline 51. & Vernonia rueppellii & Gerawa2/Reji & 0.6 & 0.31 & 1.22 & 2.13 & 0.7 & 27 \\
\hline Total & & & 100 & 100 & 100 & 300 & 100 & \\
\hline
\end{tabular}

\section{Conclusion}

Dembeza natural forest is belongs to the moist evergreen afromontane forest type of ecosystem. The forest is located with altitudinal range of $2460-2720$ m.a.s.l. during the inventory study a total of 66 plant species belongs to 41 families were recorded. This showed that the forest is high in terms of species richness and species diversity. Like other forests in Amhara region Dembeza natural forest has different natural and creature factors. Among natural factor invasive alien species (Senna didymobotrya, Argemone mexicana) 
were observed. Also, other factors recorded during the study were browsing, grazing and selective exploitation of some plant species for traditional/cultural and construction use. The regeneration status of most plant species is low. Species which have low regeneration status in the forest were Acacia lahai, Acokanthera schimperi, Calusena anisata, Dovyalis abyssinica, Dodonaea angustifolia, Rhus glutinosa, Rosa abyssinica and Steganotaeni aaraliacea. Preparing appropriate conservation method should apply for specie that has low regeneration status and less in distribution inside the natural forest. The conservation method may be ex-situ or field gene bank or enrich inside the natural forest. Species that have better regeneration status also protect from cutting and over exploitation. To sum up this study report, the forest needs responsible communities who take care as key resource and conserve in sustainable way.

\section{Recommendations}

Based on the study result on Dembeza natural forest the following recommendations are significant

1) Awareness creation should be practice to minimize communities dependence on the forest and find alternate way for the surrounding community;

2) Increase afforestation and plantation program for the forest and around the forest;

3) Documentation of plants use and traditional knowledge of communities around the forest;

4) Further studies necessary specially on plants which have low seedling and sapling regeneration status.

\section{Conflict of Interest}

The authors declare that they have no competing interests.

\section{Acknowledgements}

The authors sincerely thank Ethiopia biodiversity institute for sponsoring the inventory research. The authors also deeply thank the people in Enebsae Sar Mider District particularly community which live around Dembeza natural forest for providing their valuable information during the inventory data collection. Finally the authors truly thank the governmental officials and developmental agents for their support until the end of the survey data collection.

\section{References}

[1] WCMC 1991. Biodiversity Data Sourcebook World Conservation Monitoring Center World Conservation Press. Cambridge UK.
[2] Ensermu K, Sebsebe D. 2014. Diversity of vascular plant taxa of the Flora of Ethiopia and Eritrea. Ethiop J BiolSci 2014: $37-45$.

[3] Tadesse Z, Kelbessa E, Bekele T. 2017. Floristic composition and plant community analysis of vegetation in Ilu Gelan district, West Shewa Zone of Oromia region, Central Ethiopia. Trop Plant Res 4 (2): 335-350.

[4] Solomon Gebreyohanes 2015 community preparation on rangeland degradation: a case study in two differently settled areas of north Ethiopia. J. Agricult. Res. Dev 5 (1).

[5] GirmaBoz and MelesseMaryo 2020. Woody Species Diversity and Vegetation Structure of Wurg Forest, Southwest Ethiopia International Journal of Forestry Research Pp 17.

[6] Demel Teketay and Tamrat Bekele, 1995. Floristic composition of Dakta valley, southeast Ethiopia: an implication for the conservation of biodiversity. Mountain chronicles 15 (2): 183-186.

[7] Ethiopian biodiversity institute manual, 2014.

[8] Temesgen Mekonen, Belayneh Ayele, and Yeshanew Ashagrie. (2015). Woody Plant Species Diversity, Structure and Regeneration Status of Woynwuha Natural Forest, North West Ethiopia. J. Agric. Environ. Sci. 1 (2): 90-113 ISSN: 2636-3721.

[9] Solomon Mulu. 2009. Assessment on farmers' perception and adoption of agroforestry technologies in south Wello, north east Ethiopia. MSc thesis, Wondo Genet College of Forestry and Natural Resources, 89 pp.

[10] Getachew Mulugeta and Mesfin Admassu 2014. Woody Species Diversity and Their Preferences on Farmers' Land Holding. Journal of Natural Sciences Research 4 (9).

[11] Admassu Addi, Teshome Soromessa, Tura Bareke 2020. Plant diversity and community analysis of Gesha and Sayilem Forest in Kaffa Zone, southwestern Ethiopia.

[12] Plant diversity and community analysis 21 (7): 2878-2888.

[13] Tekle Fekadu, Dasalegn Raga and Dereje Denu 2019. Woody Species Diversity and Structure of Aba Sena Natural Forest, West Wollega Zone, Ethiopia. Ethiop. J. Educ. \& Sc. 15 (1).

[14] Tesfay Atsbha, Anteneh Belayneh Desta, Tessema Zewdu. (2019) Woody species diversity, population structure, and regeneration status in the Gra-Kahsu natural vegetation, southern Tigray of Ethiopia. Heliyon 5 e01120. doi: 10.1016/

[15] Premavani, D., NAIDU, M. T., Venkaiah, M., 2014. Tree species diversity and population structure in the tropical forests of north central Eastern Ghats, India. Not. Sci. Biol. 6 (4), $448 \mathrm{e} 453$.

[16] Demel Teketay 2001. Deforestation wood famine and environmental degradation in Ethiopia's highland ecosystems: urgent need for action. North West Africa studies 8 (1): 53-76.

[17] Central Statistics Agency of Ethiopia, 2014. Population census report, Addis Ababa Ethiopia. 